\title{
Fisiese Vakterminologie - Lief en Leed
}

Nicoline Basson

Nasionale Fisiese Navorsingslaboratorium, WNNR, Pretoria

Die tweetalige Fisikawoordeboek wat in 1977 deur die Vaktaalburo uitgegee is, het aan 'n baie groot behoefte voldoen. 'n Dinamiese vak soos die fisika vereis egter voortdurende bywerking om tred te hou met die jongste wetenskaplike en tegnologiese ontwikkelings. Met hierdie doel is 'n Fisikawoordelyskomitee, op inisiatief van Dr. A. Strasheim, byeengebring. Die komitee vergader jaarliks in Julie om aanvullende en nuwe terme, wat gedurende die jaar versamel word, te bespreek.

In hierdie bydrae word 'n paar aspekte wat 'n daaglikse betrokkenheid met fisiese vakterminologie na vore bring, toegelig.

\section{Goue Reël}

In vorige rubrieke is die verskynsel van vakbrabbel ('jargon'), oordrewe transliterasie, ens. en die probleme wat dit kan skep, reeds bespreek. In aansluiting hierby wil ek weer eens die Goue Reël by die uitbouing van vaktaal beklemtoon, naamlik om altyd die aktiwiteit of voorwerp self as uitgangspunt te gebruik en nie die bestaande Engelse/Amerikaanse/ Franse, ens. term nie.

Byvoorbeeld die terme 'hardware' en 'software' in die Rekenaarwetenskap is nie 'n duidelike beskrywing van die instrumentasie en programme wat dit veronderstel is om respektiewelik te verteenwoordig nie. Beide terme het ander gevestigde konnotasies. Daar is geen terminologiese verband tussen ' $n$ geskrewe rekenaarprogram en 'sagte ware', wat so algemeen gebruik word, nie. Boonop staan die drukstuk van die program of resultate weer as die 'hard copy' bekend. Die Afrikaanse apparatuur en programmatuur is meer beskrywend en sal hopelik algaande meer inslag vind.

'n Verdere voorbeeld is die gebruik van terme soos 'groundtruth' en 'seatruth' om die werklike waarnemings of metings op land en see te beskryf, wat dan vergelyk word met die waarnemings vanuit 'n satelliet (of vliegtuig), waarvolgens satellietdata geinterpreteer en gekalibreer kan word. $\mathrm{Na}$ heelwat deliberasie is terplaatsewaarnemings/-metings voorgestel as Afrikaanse vertaling. (Die besondere samestelling sal beter lees as dit los geskryf kon word; vergelyk egter: teraardebestelling.)

\section{Oorspronklikheid}

Die vertaling of skep van nuwe terme het bydraers al aangespoor tot groot hoogtes van oorspronklikheid. Kyk maar na: breadboard error bar error of commission error of omission grazing angle guestimate guest phase

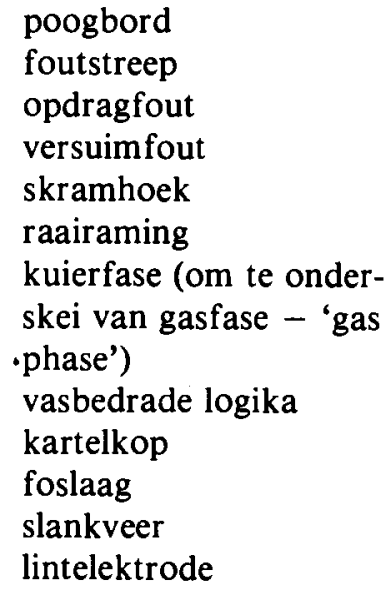

knurled knob

phoswich

slinky spring

wick electrode

\section{Struikelblokke}

Die gebruik van Afrikaans in die Natuurwetenskap is nog nie so algemeen as wat 'n mens sou verlang nie. Dit hang aan die een kant saam met die verstaanbare begeerte om liewers werk in ' $n$ internasionale taal en tydskrif te publiseer, maar aan die ander kant hou dit ook verband met die wetenskaplike se probleme met die dikwels kunsmatige en byna onleesbare Afrikaanse skryfwyse. Gelukkig kom positiewe druk gedurig deur van die Afrikaanse universiteite, waar vakterme noodwendig bevredigend vertaal moet word om die vak behoorlik te kan doseer, en van die enkele konsensieuse en kundige wetenskaplike gebruiker.

\section{Kunsmatige skryfwyse}

Die aanmekaarskryf van woorde lewer geweldig baie probleme op, veral die aaneenstrengeling van naamwoorde wat op voorskrif nie los geskryf mag word nie. As Afrikaans nog in die proses van die vorming van 'n skryftradisie is, soos in die Afrikaanse Woordelys en Spelreëls aangevoer word, dan weerspieël die aanmekaarskryf van veral tegniese terme beslis nie die volksmond of volksgebruik nie. Dit is die deskundige enkeling wat reëls soos die afstandskoppelteken volledig verstaan en reg gebruik (soos in hoof- mediese beampte, Namakwa-Mobiele Gordel). Hieronder is slegs 'n paar voorbeelde van lastige en lomp skryfwyses wat wetenskaplikes (en die alge- 
mene gebruiker) wanhopig maak omdat hulle nooit Afrikaans reg kan skryf nie. Let wel, praat lewer nie soseer probleme op nie.

besoedelstofdispersiemodel (atmosferiese wetenskappe)

Beattie- statieseveldmagnetiese anomalie (geofisika) eerstegenerasiebeeldversterkerbuis (optika)

eindige-elementmetode

elektromagnetiese-oorgangseffek-sonderingstegniek (geofisika)

energiedispersie-X-straal- analitiese fasiliteit (elektronmikroskopie)

fisikahonneursstudent (alg.)

fotö̈onisasiestabiliseringskema (lasers)

hoëdrukfisika (alg. fisika)

hoëdrukgasverkoelingstelsel (alg. fisika)

hoëtroustel (alg.)

korrosievermoeidheidkraakvoortplanting (metallur-

gie)

Meiring Naudé- Goue Medalje (alg.)

mikrokanaalbeeldversterker (optika)

radiokoolstofouderdomsbepaling (alg. fisika)

roetine-enkelgolflengtelaserspieël (optika)

sekondêrestandaarddosismeter (dosimetrie)

seldsameaarde-element

Silwerjubileum- goue medalje (alg.)

standaard-ACCOS V-bevele (rekenaarwet.)

ultrahoëvakuumsisteem (alg. fisika)

vakuumultravioletspektroskopie (spektroskopie)

vastetoestandfisika (alg. fisika)

Hierdie voorbeelde is geensins uitsonderlik nie. Dit is terme wat daagliks in die gewone omgangstaal in Afrikaans sowel as in die Engelse ekwivalent gebruik word sonder enige probleme, behalwe wanneer die Afrikaanse weergawe op skrif gestel moet word. Uit jare se ondervinding kan ek u waarborg dat min wetenskaplike gebruikers selfs $10 \%$ van hierdie voorbeelde 'reg sal spel'.

Daar kan geargumenteer word hoekom die woordorde nie verander word nie en ons liewers praat van 'ouderdomsbepaling met behulp van die radiokoolstofmetode', of 'n dosismeter wat as sekondêre standaard dien', ens. Die punt is ons praat nie so nie, maar ons Afrikaanse skryfwyse laat ons nie toe om te skryf soos ons praat nie, al is daar ook grammatikaal niks mee verkeerd om so te praat nie. Engels en Frans bv. skryf die woorde in die natuurlike spreekvolgorde sonder verlies aan begrip; Duits wel nie. Die verandering van woordorde is soms net nie moontlik nie en klink in elk geval vir die gebruiker uiters kunsmatig en daarom skryf hy liewers sy verslag, of gee hy sy lesing, in Engels want dit is minder gekompliseerd. Afgesien van die moeilike skryfwyse, lees die lang woorde nog boonop moeilik. Hierdie struikelblokke moet nie onderskat word in die sukses al dan nie van Afrikaans in die moderne tegnologies georiënteerde lewe nie.

'n Ander lastigheid wat ook in die alledaagse gebruik pla, is die kunsmatige woordorde in benamings soos die Afdeling Nasionale Meetstandaarde en Metrologie, die Sisteem Transvaal (in geologie), die Hoërskool Volksrus, ens., bloot omdat mense nie gemaklik voel oor die skryfwyse van die natuurlike praatvorm nie, nl. Nasionale Meetstandaarde en Metrologie-afdeling (asof die afdeling slegs betrekking het op metrologie) of Volksrus-hoërskool/ Volksrushoërskool, ens. Sal daar enige misverstand ontstaan as ons skryf: Volksrus Hoër Skool, Stellenbosch Distrik, die Atmosferiese Wetenskappe Afdeling, Fisika Departement, ens?

Ander voorbeelde waar aanmekaargeskryf ook probleme oplewer, is waar eiename in die saamgestelde term voorkom, soos infrarooi-Ramanverstrooiing, kwantum-Halleffek, standaard-Balzers NTS 500-ultrahoëvakuumsisteem.

Die kunsmatige skryfwyse word verder beklemtoon in die keuse van letters wat 'n akroniem of afkorting moet vorm. In Duits kry ons bv. die PTB (Physikalisch Technische Bundesanstalt); in Frans bv. die BIPM (Bureau International des Poids et $M$ esures); in Engels bv. NAC (National $A$ ccelerator Centre), NPRL (National Physical Research Laboratory), NCS (National Calibration Service). Die letters in die afkortings verteenwoordig almal onafhanklike sleutelwoorde.

Die Afrikaanse ekwivalent is

NVS: Nasionale Versnellersentrum

NFNL: Nasionale Fisiese Navorsings/aboratorium NKD: Nasionale Kalibrasiediens

Instiktief word die aaneengeskakelde naamwoorde opgebreek om die sleutelbegrippe in die afkorting te verteenwoordig.

\section{Voorstel}

'n Moontlike oplossing vir hierdie duidelik ongemaklike situasie wat ongetwyfeld die onbevange gebruik van Afrikaans as tegniese taal in die wiele ry, is dalk om alle woorde wat ' $n$ byvoeglike funksie in 'n sin of begrip vervul, in daardie konteks as 'n byvoeglike naamwoord, d.w.s. as adjektief, te behandel.

Ons doen dit reeds in uitdrukkings soos " $n$ bek-af houding', 'n raad-op man' (Afr. Woordelys en Spelreëls, Hfst. VII), waar nié bek-af of raad-op bona fide byvoeglike naamwoorde is nie, maar wel die funksie daarvan het. Ook mag maksimum, minimum en optimum in samestellings los of vas geskryf word afhangend daarvan of hulle as byvoeglike naamwoorde of selfstandige naamwoorde beskou word. Met standaard, roetine, lang- en korttermyn, wat meestal 'n byvoeglike funksie in samestellings het (standaardafwykng, roetinetaak, langtermyndoel), mag dit nie gedoen word nie. Om hierdie en ander samestellings los te skryf kan nie afbreuk doen aan die begrip of aan die leesbaarheid nie, eerder die teenoorgestelde.

\section{Ten slotte}

Om Afrikaans as tegniese taal te laat inslag vind en lewenskragtigheid te laat verwerf, sal groter buigsaamheid in die skryfwyse ingestel moet word. Taalreëls en skryfwyse moet toeganklik wees vir die algemene gebruiker en nie net vir 'n handjievol taaldeskundiges nie. 